\title{
Congregation of Apis cerana indica Fabricius 1798 drones in the canopy of trees in Sri Lanka
}

\author{
RWK Punchihewa1 ${ }^{1}$ N Koeniger ${ }^{2}$, G Koeniger 2 \\ ${ }^{1}$ Sri Lanka Department of Agriculture, Agriculture Research Station, \\ Makandura, Gonawila (NWP), Sri Lanka; \\ ${ }^{2}$ Institut für Bienenkunde, Polytechnische Gesellschaft, Fachbereich Biologie \\ der Universität Frankfurt a M, Karl-von-Frisch-Weg 2, D 637 Oberursel, FRG
}

(Received 24 August 1989; accepted 22 February 1990)

\begin{abstract}
Summary - Drone congregations of Apis cerana in Sri Lanka were found in the canopy of trees. The space in which the drones were flying had distinct borders demarcated horizontally and vertically by the canopies of trees: the area was about $10 \times 6 \mathrm{~m}$ and the height of flight was between $4 \mathrm{~m}$ and $8 \mathrm{~m}$. Some drones $(n=118)$ were caught and marked at the congregation area. Marked drones were found within a radius of $100 \mathrm{~m}$ of each drone colony. The rate of recovery was $92 \%$ after $24 \mathrm{~h}$. Therefore, the flight range of the drones was very limited. The differences between the drone congregation areas in Sri Lanka and the DCAs of Apis mellifera in Europe are discussed.
\end{abstract}

Apis cerana / reproduction / mating behaviour / drone congregation / Sri Lanka

\section{INTRODUCTION}

Honeybee drones leave the colony and conduct their mating flight activity during a distinct and often species-specific period of the day (Koeniger and Wijayagunasekera, 1976; Koeniger et al, 1988). The drones assemble above certain areas where they remain flying in large groups. Drone congregation areas (DCA) have been described in Europe (Ruttner and Ruttner, 1965a), in North America (Zmarlicki and Morse, 1963) and in Africa (Ruttner personal communication). No reports on DCA's are available from Asia. Some DCAs are well documented and drones have been found there each summer for more than 25 years (Koeniger et al, 1988). However, it is not yet known which factors cause the drones to visit these locations. All DCAs known to us are open places, which are away from larger trees or higher vegetation. DCAs are mainly known for the Western honeybee Apis mellifera. The only report of Apis cerana came from Oberursel, FRG. There, drones of imported $A$ cerana colonies (originating from North Pakistan) were caught in a DCA in an equal proportion compared to drones of Apis mellifera (Ruttner, 1973). DCAs in the natural habitat of Apis cerana have not yet been described.

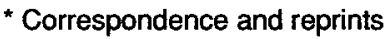




\section{MATERIAL AND METHODS}

Prior to the experiments described in this paper we detected 3 drone congregation areas in $\mathrm{Ma}-$ kandura (Kurunelgala District) in autumn 1988. Our plans to study these DCAs failed. Because of unfavourable weather conditions the colonies eliminated most of the drones. Therefore, we already had some ideas and experience on Apis cerana DCAs before we began our experiments in March and April 1989.

The experimental site at Padukka (Colombo District) is situated in a mixed crop area (coconut and a large variety of fruit and spice trees) adjoining a rubber (Hevea brasiliensis) plantation. Apis cerana colonies were already taken to Padukka in February. In this way, colonies adapted well to the rubber honey flow which usually occurred in March and produced and maintained larger numbers of drones. Eleven colonies kept in movable frame hives were scattered in the experimental area (fig 1). During March and to the end of April, all colonies kept large numbers of drones.

The drone flight occurred regularly during 15.30 h-17.00 hours under fair weather conditions (we did not work on cloudy and rainy days). The temperature was $29^{\circ} \mathrm{C}$ to $31^{\circ} \mathrm{C}$ and relative humidity was $60-70 \%$. There were none or very slight winds from a westerly direction.

For attracting drones, we used a living Apis cerana queen in a small cage or more frequently, black cotton dummies $(5 \mathrm{~mm}$ thick and $2 \mathrm{~cm}$ long) which were contaminated by $1 \mathrm{mg}$ of synthetic 9-oxo-2-decenoic acid (9-OD). The dummy was tied to a balloon filled with hydrogen (Ruttner and Ruttner, 1965a) and presented during the period of drone flight in different places and heights. We counted the number of drones attracted to the dummy at 1 min intervals using a hand tally. After each count, the balloon was pulled down and moved to another counting point (fig 1). We were able to count accurately when small numbers of drones visited the bait. When larger numbers of drones were attracted we stopped counting at 100 . In addition, when drones remained hovering in larger swarms or clouds around the dummy these cases were added under the label of "more than 100". In order to catch drones we used an insect net fixed to a bamboo pole $(4 \mathrm{~m}$ ) (fig 2). The drones were marked with a spot of coloured paint in each DCA and released at once. We inspected the colonies during the early morning hours (well separated from the time of drone flight) and counted the painted drones.

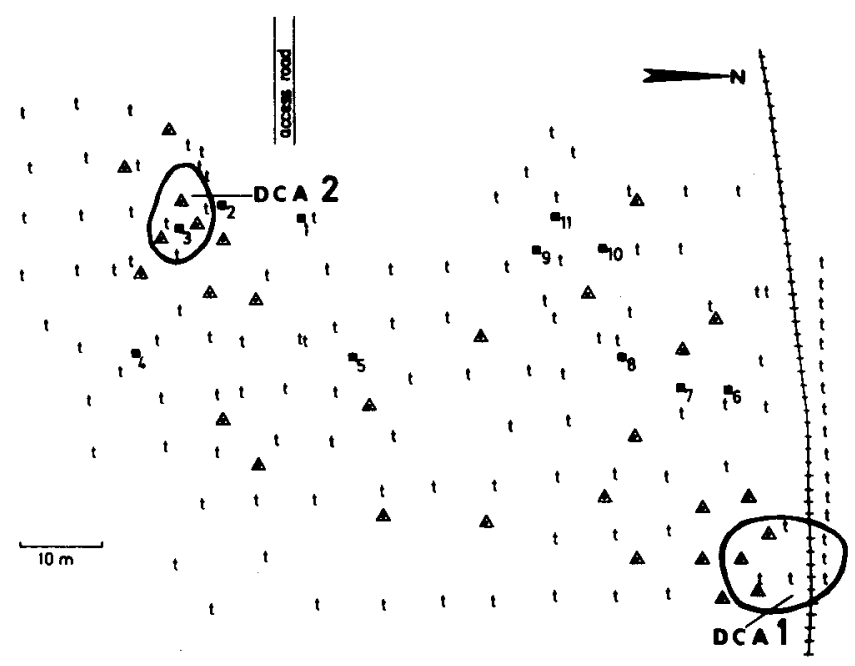

Fig 1. Experimental site in Padukka. — border line of DCA (within the border line the hum of drone flight was audible); $\mathbf{\square}$ drone colonies; $\Delta$ counting points; $t$ trees (mainly coconut palms); fence. 


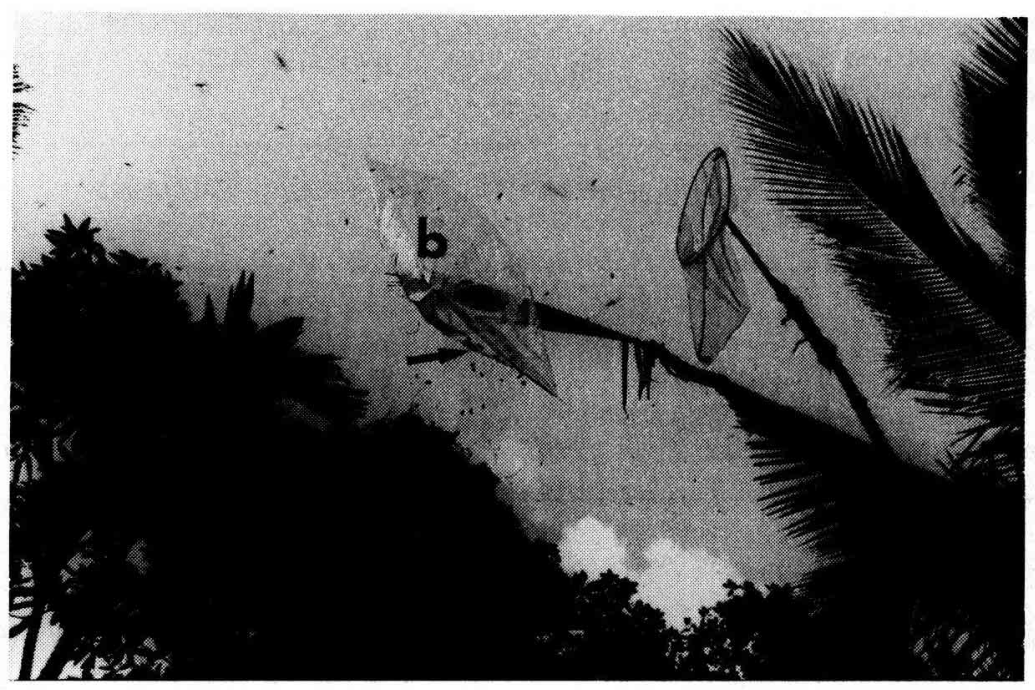

Fig 2. Swarm of drones around the bait is caught by an insect net. b balloon; $\rightarrow$ bait ( $1 \mathrm{mg} 9-\mathrm{OD})$.

\section{RESULTS}

\section{Horizontal distribution of drones}

Using a hydrogen balloon and a bait with 9-OD we discovered several DCAs of Apis cerana in Sri Lanka. All of them were found in places with high vegetation, trees with a height of $5-10 \mathrm{~m}$. Due to the vulnerable hydrogen balloon, the bait had to be carefully manœuvred into the canopy from above or from the sides. Larger numbers ( $>100$ ) of drones would always be attracted and remain in clusters around the bait in a very small and distinct space, which was either within or very close to the limits of the canopy of the taller trees. No DCA was detected in the free space above or beside the foliage of the trees.

We chose the experimental area at $\mathrm{Pa}$ dukka to conduct a systematic search for DCA locations. There we found 2 locations (fig 1, DCA1 and DCA2) where a distinct "hum" of flying drones was audible. At these locations we saw no drones flying until we threw stones in the air to which the drones reacted by slowing down their flight. Similar behaviour was observed by the dragon fly, butterflys or other flying insects passing through the space of the DCA.

A systematic screening of the area with the balloon and the 9-OD bait at a height of $5 \mathrm{~m}$ revealed that only within $\mathrm{DCA}_{1}$ and $\mathrm{DCA}_{2}$ were we able to attract large numbers of drones which formed clusters and swarms around the bait. Outside these locations we frequently saw single drones flying towards the bait but they passed quickly. Further, drones left the bait when we moved it away from the DCAs. We counted the number of drones per min at different places within the experimental area (fig 1). A clear distinction between the DCA and the surrounding became apparent (table I). 
Table I. Horizontal distribution of drone frequency at the bait ( $5 \mathrm{~m}$ above the ground).

1 Drones were counted by periods of 1 min; ${ }^{2}$ Number of periods of counting; ${ }^{3}$ Number of points where we counted (position see fig 1).

\begin{tabular}{lrcccr}
\hline & $\begin{array}{r}\text { Inside } \\
\text { DCA 1 }\end{array}$ & $\begin{array}{c}5 \text { m outside } \\
\text { DCA 1 }\end{array}$ & Middle zone & $\begin{array}{c}5 \text { m outside } \\
\text { DCA 2 }\end{array}$ & $\begin{array}{c}\text { Inside } \\
\text { DCA 2 }\end{array}$ \\
\hline $\begin{array}{l}\text { Drones/min }{ }^{1} \text { (average) } \\
\text { \# of counts }{ }^{2}\end{array}$ & $>100$ & 37 & 10 & 61 & $>100$ \\
\# counting points & 38 & 53 & 121 & 44 & 37 \\
Distance $(\mathrm{m})$ & 3 & 4 & 15 & 5 & 3 \\
\hline
\end{tabular}

\section{Vertical distribution of drones}

Our counts at 2-8 $\mathrm{m}$ above ground showed a clear vertical distribution of drones. When the bait was kept below the canopy of the trees only a few drones were attracted. Within the trees' canopy we observed large numbers and witnessed swarm formation. Few or no drones responded to the bait above the trees over the canopy. The drone counting revealed a maximal reaction at a height of 4-6 m (table II, fig 3). During our experiments weather conditions remained fair, and we were therefore unable to observe the effects of different temperatures or wind speed on the drones' behaviour.

\section{Contribution of colonies to the drone population of the DCAs}

On April 11th and 12th we caught and painted (white) a total of 128 drones in $\mathrm{DCA}_{2}$. On the morning of April 13th we found 118 of the marked drones in the colonies which equals a recovery rate of $92 \%$. Some bees were marked in each drone colony (table III).
In $\mathrm{DCA}_{1}$ we painted (yellow) 44 drones on April 13th and recovered $23(52 \%)$ of them in the colonies $7 \mathrm{~d}$ later (table III). In these experiments we looked for drones on 16 days and found them each in $\mathrm{DCA}_{1}$ and $\mathrm{DCA}_{2}$.

\section{DISCUSSION}

Our observations and experiments are the first description of a DCA of Apis cerana in Asia. Our results are still limited to a small number of places and to short periods of

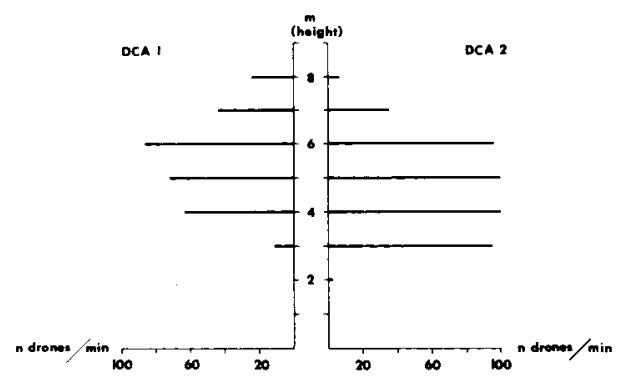

Fig 3. Drone flight in different heights in the DCAs. $n$ drones/min : number of drones counted at the bait in $1 \mathrm{~min} ; \mathrm{m}$ (height) : height of the bait in $\mathrm{m}$ above the ground. 
Table II. Vertical distribution of drone frequency in the DCAs. Height is given in meters above the ground. $n=$ mean number of drones counted in a period of $1 \mathrm{~min}$.

\begin{tabular}{cccccccc}
\hline Height $(m)$ & 2 & 3 & 4 & 5 & 6 & 7 & 8 \\
\hline DCA1 & 0 & 11 & $>100$ & $>100$ & $>100$ & 44 & 24 \\
& $n=14$ & $n=14$ & $n=14$ & $n=14$ & $n=14$ & $n=14$ & $n=14$ \\
DCA2 & 3 & $>100$ & $>100$ & $>100$ & 97 & 38 & 8 \\
& $n=13$ & $n=13$ & $n=13$ & $n=13$ & $n=13$ & $n=13$ & $n=9$ \\
\hline
\end{tabular}

observation. We do not know as yet whether the type of DCA observed is the only one or even the typical Apis cerana DCA in Sri Lanka. However, because of its unique features it seems of significant interest to discuss the similarities and differences between DCAs described for Apis mellifera and the space in the canopy of coconut palms where we found the assemblies of Apis cerana drones (fig 4).

The DCAs which we found in Sri Lanka seem to share several similar qualities compared to an Apis mellifera DCA. In both instances the drones accumulate above certain areas. Only within these locations is the humming noise of flying drones audible. Inside the DCA, the drones form clusters and remain at the queen or 9-OD dummy (fig 2). Drones do not follow a bait beyond the borders of the DCA. Rather, they leave the bait and stay in the DCA. Outside the borders of the DCA only single drones pass the bait in rapid flight. The DCA is visited by drones from many colonies in the area. Therefore,

Table III. Distribution of drones marked in DCAs and percentage of captured drones recovered.

* $1 \mathrm{~d}$ after capture in DCA; ${ }^{* \star} 7 \mathrm{~d}$ after capture in DCA.

\begin{tabular}{|c|c|c|c|}
\hline Col No & Drones marked & In DCA2 & $\ln D C A 1$ \\
\hline 1 & & 15 & 2 \\
\hline 2 & & 19 & 0 \\
\hline 3 & & 11 & 2 \\
\hline 4 & & 19 & 3 \\
\hline 5 & & 7 & 0 \\
\hline 6 & & 6 & 1 \\
\hline 7 & & 4 & 0 \\
\hline 8 & & 13 & 7 \\
\hline 9 & & 11 & 4 \\
\hline 10 & & 7 & 3 \\
\hline \multirow[t]{2}{*}{11} & & 6 & 1 \\
\hline & Recovery rate & $92 \% *$ & $52 \% * *$ \\
\hline
\end{tabular}




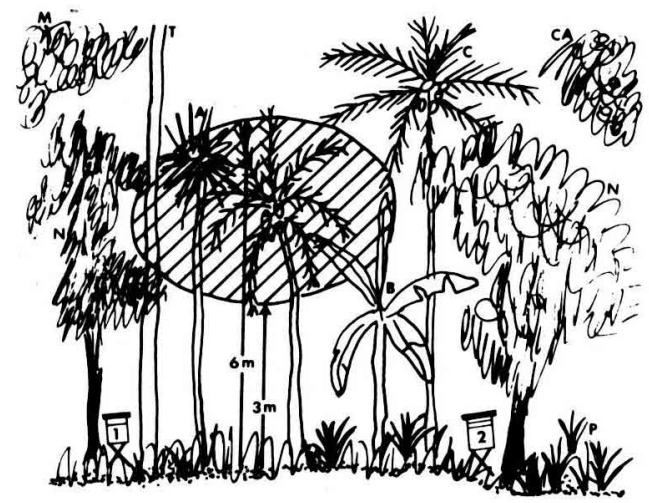

Fig 4. Drawing of DCA2 (hatched area). Arecanut : Areca catechu; Cashow = Anarcardium occidentale; Coconut $=$ Cocos nutifera; Mango = Mangifera indica; Nam nam = Cymometra cauliflora.

the function of a DCA as a genetic outbreeding mechanism seems to be similar in both species.

However, in some features the DCAs in Sri Lanka show differences compared to the DCAs of Apis mellifera. The space in which the drones of Apis cerana accumulate is smaller and more distinct. Further, the DCAs are in coconut or rubber plantations or other areas with larger trees. The drones restrict their flight to a space within the canopies of the trees. Drones do not follow the bait into the open space above the canopy. Apis mellifera drones are reported to congregate in open air above their DCA. The area measured by radar is reported to be $1600 \mathrm{~m}^{2}$ (Loper et al, 1987). We still do not know whether Apis cerana drones visit the same place for several years as reported for Apis mellifera. However, the structure of the trees' canopy is variable and we expect the DCAs to shift accordingly. We have no idea why the Apis cerana drones visit this location and not another one. In Apis mellifera it is still unknown what local conditions make the drones stay or return to a DCA (Ruttner and Ruttner, 1966). The distance between a DCA in Sri Lanka and the drones' colonies is within a radius of $500 \mathrm{~m}$. Further, the high recovery rate $(92 \%)$ of the marked drones in the colonies being less than $100 \mathrm{~m}$ from the DCA seems to support the idea of a short mating distance.

Drones of Apis mellifera were found visiting a DCA at a distance up to $8 \mathrm{~km}$ from their colonies (Ruttner and Ruttner, 1965b). Experiments on the flight range of Apis cerana drones in Sri Lanka are the subject of our research program, especially since the natural flight range of Apis cerana (worker bees) in Sri Lanka is much shorter than the flight radius of European Apis mellifera (Punchiheva et al, 1985).

For practical purposes, a short mating distance offers some advantages for installing breeding stations for controlled mating. A regional breeding program in which Apis cerana can be selected and bred on a small local level seems to be feasible.

In Germany, Apis cerana cerana drones originating from Pakistan visit a DCA of Apis mellifera (Ruttner, 1973). Therefore, the differences between the DCAs in Sri Lanka and the European DCAs do not relate to a species-specific difference in mating biology between Apis mellifera and Apis cerana. It is more likely that the features of a DCA are the result of local adaptations to environmental factors as for example avoiding predators (Merops spec etc). In Africa at the slope of Mount Kilimanjaro $A$ mellifera monticola drones seem to congregate and fly at the height of tall trees (Ruttner 1986 personal communication). 


\section{ACKNOWLEDGMENTS}

The Sri Lanka Department of Agriculture supported this research by providing facilities and equipment. PD Karunasena of Paddukka offered his land for the experiments. The DAAD (German Academic Exchange Service, Project No $325817005 / 8$ ) sponsored the participation of the senior author in a research and training programme at Oberursel (FRG) where some of the experimental techniques were developed. CIDA (Canadian International Development Agency, Project No 270/12061) supported us with essential equipment. We acknowledge this assistance and thank all parties for their generous co-operation.

Résumé - Lieux de rassemblements de mâles d'Apis cerana indica Fabricius 1798 dans la canopée des arbres au Sri Lanka. Des rassemblements de mâles d'Apis cerana ont été trouvés dans la canopée des arbres au Sri Lanka à l'aide des méthodes classiques (Ruttner et Ruttner, 1965a) : ballon gonflé à l'hydrogène avec une reine ou un leurre imprégné de phéromone de reine. L'espace dans lequel volent les mâles est bien délimité : horizontalement, il s'étend sur $10 \mathrm{~m} \times 6 \mathrm{~m}$ environ (tableau I, fig 1) et verticalement, entre $3 \mathrm{~m}$ et $8 \mathrm{~m}$ au-dessus du sol (tableau II, fig 3). A l'intérieur de ces limites de nombreux mâles ont pu être attirés. Ils restaient longtemps près du leurre en formant un essaim ou passaient rapidement en volant près du leurre. Des mâles ont été capturés à l'aide d'un filet sur le lieu de rassemblement (LRM) et marqués (fig 2). Le lendemain matin, $92 \%$ des mâles marqués furent retrouvés dans des colonies situées dans un rayon de $100 \mathrm{~m}$. Le rayon de vol des mâles d'Apis cerana au Sri Lanka semble donc beaucoup plus réduit que celui des mâles d'Apis mellifica (jusqu'à 8 km). Dans les 11 colonies étudiées, il n'y avait qu'1 seul mâle marqué. Un accouplement sur le LRM conduit donc, comme chez Apis mel- lifica, à un mélange du patrimoine génétique. D'après des recherches antérieures faites à Oberursel (RFA), les mâles d'Apis cerana cerana, issus de colonies importées du Pakistan, ont visité un LRM d'Apis mellifica et y ont été trouvés en proportions égales avec les mâles de $A$ mellifica (Ruttner, 1973). Les différences entre les LRM dans la canopée des cocotiers et des autres arbres du Sri Lanka (fig 4) et les essaims de mâles en l'air au-dessus des prairies et des champs en Europe semblent donc être plutôt une adaptation aux facteurs écologiques (prédateurs et autres) qu'une différence spécifique. Une observation de $F$ Ruttner va également dans ce sens : un LRM d'Apis mellifica monticola a été observé sur les pentes du Kilimandjaro à la hauteur de la cime des arbres.

Apis cerana / reproduction / comportement d'accouplement / rassemblement de mâles / Sri Lanka

Zusammenfassung - Drohnensammelplätze von Apis cerana indica im Laubdach der Bäume in Sri Lanka. Mit den klassischen Methoden (Ruttner \& Ruttner, 1965a), Wasserstoffballon mit Königin oder Königinnenpheromon als Köder, wurden in Sri Lanka Drohnenansammlungen von Apis cerana im Laubdach der Bäume gefunden. Dabei wurden klare Grenzen für den Flugbereich der Drohnen nachgewiesen. Die horizontale Ausdehnung (Tabelle I, Abb 1) betrug etwa $10 \mathrm{~m} \times 6 \mathrm{~m}$ und die Flughöhe lag zwischen $3 \mathrm{~m}-8 \mathrm{~m}$ über dem Boden (Tabelle II, Abb 3). Nur innerhalb dieser Grenzen konnten große Zahlen von Drohnen angelockt werden, die als Schwarm längere Zeit am Köder verweilten. Außerhalb wurden lediglich kurze Vorbeiflüge von Drohnen am Köder beobachtet. Aus der Drohnenansammlung wurden mit einem Netz Tiere gefangen (Abb 2) und markiert. Am nächsten Morgen wur- 
den $92 \%$ der gezeichneten Drohnen in Völkern innerhalb eines Radius von $100 \mathrm{~m}$ wiedergefunden. Damit scheint der Flugradius der Apis cerana Drohnen in Sri Lanka wesentlich kleiner als der von Apis mellifera (bis zu 8 km !) zu sein. In allen 11 Versuchsvölkern fanden sich einzelne gezeichnete Tiere, so daß eine Paarung in der Drohnenansammlung wie bei Apis mellifera zu einer Durchmischung des Erbgutes führt. Nach früheren Untersuchungen in Oberursel (Bundesrepublik) besuchten dort Apis cerana cerana Drohnen, die aus Importvölkern aus Nordpakistan stammten, einen Apis mellifera Sammelplatz und waren dort in gleicher Proportion vertreten wie die mellifera Drohnen (Ruttner, 1973). Damit scheinen die Unterschiede zwischen den Drohnensammelplätzen im Laubdach der Kokospalmen und der anderen Bäume von Sri Lanka (Abb 4) und den Drohnenschwärmen im freien Luftraum über den Wiesen und Feldern in Europa eher Anpassung an Räuber und andere ökologische Faktoren zu sein als Artunterschiede. In diese Richtung deutet auch eine Beobachtung von Ruttner, der 1986 einen Drohnensammelplatz am Abhang des Kilimanjarao gefunden hat. Dort flogen die Drohnen der afrikanischen Bergbiene Apis mellifera monticola in Wipfelhöhe der Bäume.

\section{Apis cerana / Fortpflanzung / Begat- tungsverhalten / Drohnensammelplatz / Sri Lanka}

\section{REFERENCES}

Koeniger G, Koeniger N, Pechhacker $H$, Ruttner $F$, Berg S (1989) Assortative mating in a mixed population of European honeybees (Apis mellifera carnica, Apis mellifera ligustica). Insectes Soc 36, 129-138

Koeniger N, Wijayagunasekera HNP (1976) Time of drone flight in the three Asian honeybee species (Apis cerana, Apis florea, Apis dorsata). J Apic Res 15, 67-71

Koeniger N, Koeniger G, Tingek S, Mardan M, Rinderer TE (1988) Reproductive isolation by different time of drone flight between Apis cerana and Apis vechti. Apidologie 19 (1), 103106

Loper GM, Wolf WW, Taylor Jr, OR (1987) Detection and monitoring of honeybee drone congregation areas by radar. Apidologie 18 2, 163-172

Punchihewa RWK, Koeniger N, Kevan PG, Gadawski RM (1985) Observations on the dance communication and natural foraging ranges of Apis cerana, Apis dorsata and Apis florea in Sri Lanka. J Apic Res 24, 168-175

Ruttner F (1973) Drohnen von Apis cerana auf einem Drohnensammelplatz. Apidologie 4 (1), 41-44

Ruttner F, Ruttner H (1965a) Untersuchungen über die Flugaktivität und das Paarungsverhalten der Drohnen II. $Z$ Bienenforsch 8 , $1-9$

Ruttner F, Ruttner H (1965b) Untersuchungen über die Flugaktivität und das Paarungsverhalten der Drohnen III. $Z$ Bienenforsch 8 , 332-354

Ruttner F, Ruttner H (1966) Untersuchungen über die Flugaktivität und das Paarungsverhalten der Drohnen IV. $Z$ Bienenforsch 9, 259-265

Zmarlicki C, Morse RA (1963) Drone congregation areas. J Apic Res 2, 64-66 